\title{
Problems of ecology and ensuring environmental safety in relation to toxic "Krasny Bor" dump site
}

\author{
Elena Smirnova ${ }^{1^{*}}$ \\ ${ }^{1}$ Saint Petersburg State University of Architecture and Civil Engineering, Vtoraja Krasnoarmejskaja \\ Str. 4, 190005, St. Petersburg, Russia
}

\begin{abstract}
In the article the author raises the problem of ecology and ensuring environmental safety in relation to toxic "Krasny Bor" landfill. Comprehensive analysis of the existing system shortcomings to storage toxic industrial waste has been given. The principal threats of a dangerous object to the environment being in a critical state have been discussed. Reliable and high-quality environmental monitoring in the landfill is still absent. At all stages of the life cycle of the "Krasny Bor", bureaucratic confusion impedes the development of environmentally oriented investment activities for the reclamation of toxic pits. The main elements of the project structure to remediate the "Krasny Bor" have been considered. It has been shown that the project must include all acceptable technological solutions related to landfill disposal and that it is necessary to focus on environmental protection and environmental safety of the area. In the framework of current situation at the disposal site, it does not seem impossible to solve the issues of ensuring environmental safety in the direction of moving towards sustainable and balanced development of the North-West region.
\end{abstract}

\section{Introduction}

In 2014 the unitary enterprise "Krasny Bor" dump site lost the right to handle hazardous waste. However, they continued to bring industrial waste to it, since the situation was desperate: the factories of the city had to adhere to the requirements on handing over dangerous waste, but there was no other place except "Krasny Bor" to bring the waste. In 2016 the Federal Service for Supervision of Natural Resource Usage for North-Western Federal District filed a lawsuit in order to deprive the unitary enterprise of the license for placement of industrial waste in the open pits No.67, No.66 and No.59 not compliant with nature protection requirements. The decontamination of non-organic waste has violated flagrantly the process regulations of preserving the bulk structure of blue clays and protection of subsoil water against contamination with toxic pollutants located in these cells. According to the legal proceedings the landfill management has violated flagrantly beginning from 1999 the instructions on ecological safety provided for in the license (e.g.,

\footnotetext{
* Corresponding author: esmirnovaee@mail.ru
} 
$p H$ value in the cells was below 6). The enterprise has been stopped repeatedly. The creditor indebtedness of the landfill site to counteragents as well indebtedness with respect to taxes, duties and fines exceeded $990 \mathrm{mn}$ RUB. Since multiple departments and lower organization deal with functions of monitoring state of the environment, abidance by legislation, etc., a reliable system of ecological monitoring (implementation of full closed cycle of facility assessment from conducting expert appraisal to suspending operation due to violated legislation on environmental protection) of the landfill site is still absent. The deliberate violations of ecological legislation and environmental management (receiving waste at night, fires in cells, blowouts of liquid waste into main channel in the period of high waters and rains), abuse of authority, etc. have resulted in the fact that presently the landfill site is one of the most dangerous industrial facilities in the territory of the NorthWestern Federal District.

The landfill site has been arranged on the lands intended for agriculture proceeding from the results of engineering survey works of employees of LLC "Sevzapgeology". Within 48 years from 1966 to 2014 the industrial toxic waste has been brought to the site with no intention to extract it and process in future. The deliveries to "Krasny Bor" have been performed even from the Baltic region. Many researches have an opinion in the course of assessing destructive contamination of the landfill site on the state of the environment, that it is unparalleled by the level of urgency and resembles a slow-maturing "Chernobyl" [1-2]. The threat of "Krasny Bor" to ecological safety of the environment has got a scope of the federal emergency situation: recently the landfill site has passed under the control of the Ministry of Natural Resources and Environment of the Russian Federation. The toxicity of "Krasny Bor" is an extremely dangerous man-induced phenomenon threatening SaintPetersburg as the biggest metropolitan city of the country, the Neva river flowing through it and the biggest in Russia Ladoga lake providing potable water optimal by its composition to the residents of the "cultural capital" (Fig. 1).

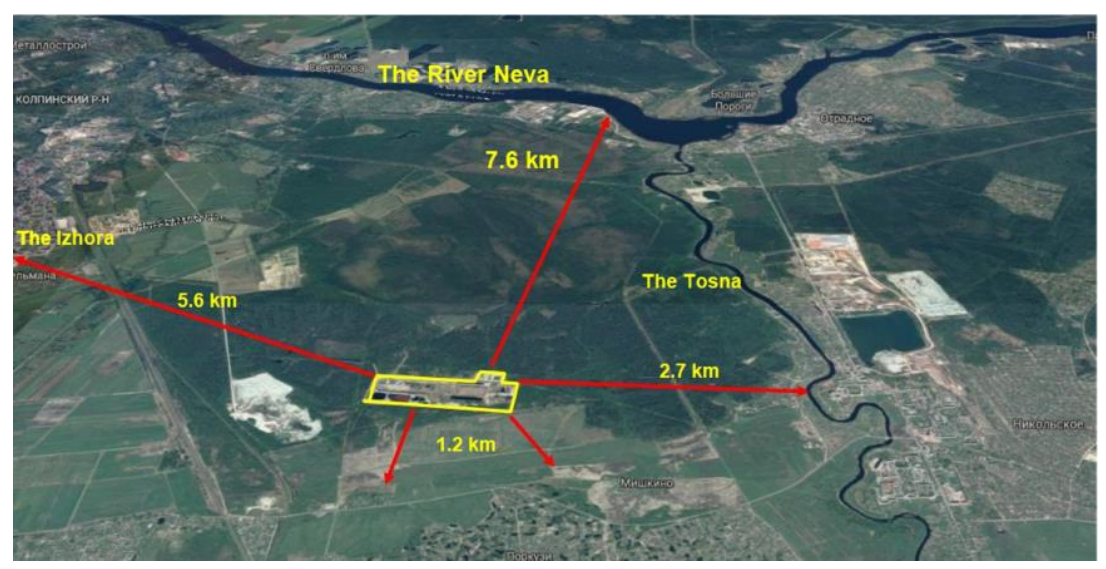

Fig. 1. "Krasny Bor" landfill site is a source of high environmental hazard.

It is necessary to keep in mind that not only Ladoga and full-flowing Neva running out of it are endangered, but also 50 thsd small lakes and 60 thsd small rivers and rivulets forming a consolidated water basin therewith in the North-West [3-5].

A development of any region should meet the standards of sustainable development. This general idea implies creation of natural-and-engineering systems, which functioning fully complies with the criteria of ecological safety. Stated differently, an equilibrium economical and social state of some territories should be given top priority with preservation of self-sustainable habitat. The solution of this task will be attained in the process of constructive interaction of people and nature, in order to exclude completely the 
man-induced solutions not working for the specific features of territories. Otherwise, the anthropogenous factor will bring about a fundamental negative transformation of landscapes and violation of stability of eco-economic structure of the North-West [6-7]. From this point of view the problem of remediation of "Krasny Bor" landfill site is an extremely challenging one for creation and protection of favorable conditions vital functions of local community. Different scholars notice a negative impact of the maninduced system of the landfill site on the environment. They distinguish an unstable ecological situation around "Krasny Bor". So, for example, high contents of heavy metals have been revealed in the hair of children living in close proximity to a bio-negative facility [8]. A decision on construction of the high-danger industrial facility on moving blue clays was an erroneous and unjustified one. No special attention has been paid to studying a problem of risk of soil shear under conditions of swelling thereof [9]. Just as regular changes can be observed in the connection of blocks depending on the depth of occurrence in clayey rock mass featuring definite structural and tectonic peculiarities depending on geological history of the region, so the geotechnical evaluation of blue Cambrian clays should be authentically correlated with potential insecurity of structures being built thereupon. The fracture can be revealed not only in the magmatic rock with crystalline structure, but in the majority of sedimentary deposits featuring high level of lithification. Put it in other way, the landfill site is under conditions of high fault rate and risk of ecological emergency situation [10-11].

Since the economic activity of a man impacts the quality of environment, the system of ecological monitoring is an efficient mean of environmental management [12]. Though, an issue of eco-economic equilibrium until now gives rise to acute discussions and remains as one of the most challenging [13]. The maximum contribution to the development and implementation of this system has been made by D.L. Meadows, J. Randers, D., W. Behrens, D.H. Meadows, B. Commoner, et al. [14-15]. The works of V.I. Vernadsky, N.F. Rejmers, V.I. Telichenko, M.Y Slesarev and many other scholars can be distinguished among Russian scholars [16-18].

A further destruction of natural environment by "Krasny Bor" landfill site will result in the loss of standard properties and functions of the North-West territory. A transformation of natural-resources potential and replacement of natural landscapes with anthropogenic ones will take place. In this respect the authors face the following tasks: assess the indicators of state and functional integrity of the ecological system of "Krasny Bor" dump site, reveal the reasons of changing these indicators; forecast the consequences as a result of such changes; determine corrective measures for rectifying the emerging negative situations. The goal is as follows: creating positive environment for the life activity of people and business, which could become a basis for supporting health and employability of the people, well-balanced economic development of the North-West of Russia.

\section{Materials and Methods}

The author uses a method of comparative analysis, which helped to structure the material for understanding the functional integrity of the ecological system of "Krasny Bor" and make findings regarding consequences that may occur in case of emergency situation. At the beginning of landfill site building an academic interest has been connected with studying influence of the buried industrial chemical waste on the adjacent territory. Gradually in the course of accumulation of waste and absence of efficient means for treatment thereof and subsequent disposal the attention of researchers has switched over from a descriptive approach and unambiguous, sometimes misguided notions and reports to diversified interdisciplinary deliberations on the role of components in functional integrity of the ecological system: surface and subsurface water, hydrogeochemical composition of 
rock, state of the ground and atmosphere around landfill site, cells flooding in the periods of high water, etc. The health problems have come into the spotlight with all urgency due to contamination of subsurface water of the North-Western region, absence of understanding of urgency of this scenario of developments. In this respect we proceed in our scientific justification from the well-proven dynamic model of Meadows group. Its main point consists in the fact that the consumption of natural resources and environmental damage bring about more and more unpredictably an utterly unfavorable (basic) scenario of society development, which indicators are as follows: accelerating industrialization, population growth, threat of food shortage, depletion of resources, environmental degradation [14]. Any unnatural changes in the ecological system will inevitably result in the irreversible alterations. A danger of harmful and toxic chemical substances, which have never existed in nature (dichloro-diphenyl-trichloroethane, polypropylene, polyethylene, etc.) consists in the fact that these substances do not participate in the natural process of redistribution, get accumulated and have a negative effect on the environment. The man-induced systems have posed the waste disposal problem to people. This is why the subject of waste-free production is so relevant. An extreme care is required in the activities on environment transformation. It will be necessary to pay either way for the development not compliant with the goals of ecological safety by degradation of the immediate environment of human livelihood [15].

It is also important to point out the methodological value of a sustainable development model engineered by N.F. Rejmers, according to which no margin of safety is left with nature, including a human-being as a biological entity. It is necessary to scientifically substantiate nature protection and provision of environmental safety in the man-induced zones and zones potentially dangerous with emergency situations [17]. The author's analysis is supported by the fundamental significance of the second biochemical law of V.I. Vernadsky [16] stating that the natural-resources potential should not be lower than the level of resources extraction and rate of changing the living environment of people and that migration of chemical elements takes place in biosphere with mandatory direct or indirect participation of living organisms. Any losses in composition of "living material" will call forth a dramatic destruction of the entire biogeochemical system. The intensity and versatility of impacts of toxic industry have already exceeded the rate of adaptation of natural ecosystems. The author believes that in order to minimize the man-induced impacts on the ecosystem, timely reveal potentials of dangerous development, the complex of the above principles helps duly assess the state of environmental safety of engineering solutions for "Krasny Bor".

\section{Results}

The location of "Krasny Bor" landfill site for burial of chemical waste of classes of danger I-IV has been chosen according to the requirements to soils characteristics and classification of waste neutralization technologies. The site selection has been substantiated by the fact that deep (down to $120 \mathrm{~m}$ ) occurrences of blue early-Cambrian clays with unique water-resistant properties in this territory will provide leak-proofness of the cells with chemical waste and prevent penetration of liquid waste to environment. This is hardly imaginable that the most ancient sludge deposits, which had emerged at the germ of life due to vital functions of aerobiotic photosynthetics, would become millions of years later a subject of designing pits for burial of utterly harmful pollutants connected to death, destruction and negation of life as it is. Just imagine that the emergence of the greater part of chemical elements of the Mendeleev's table, on the contrary, was related to the advent of life on the Earth! After all, the early-Cambrian clays owe in some measure water resistance and plasticity thereof to preservation of colloidal sulphide as the product of activity of 
primitive life therein. The emerging various microorganisms: cyanobacteriae, sulphur reducing bacteria, phytoplankton, bottom-living microorganisms, the smallest multilocular vermicular organisms (and so many more intricate forms have not survived and have not come down to us) have transfigured the deposit material forming free oxygen as the source of life as a result of photosynthesis. The vortex-like colloform germination compositions appropriate of blue clays inform us on the decisive role of bacterial activity as the "living material" in the development of life on the Earth. If one can imagine that the clayey layer of $1 \mathrm{~mm}$ have accumulated during 100 years (while the thickness of blue clays reaches $120 \mathrm{~m}$ in the area of the landfill site), we may only wonder how stormy and majestic was the transformation of firm land sinking into underwater world as a result of volcanic disturbances! That is to say, an extreme uniformity and thereby water-resistance of blue clays depict an ancient "pulse" of the Earth, a pulsation of the "living material" on the Earth. It is interesting that Sablino, a settlement located on blue clays, is known as a natural pearl of Saint Petersburg's surroundings! There was no mistaking on the part of the scientists of LLC "Sevzapgeology", "Giprovodkhoz" and other structures, therefore, the original plans on building a landfill site have envisaged receiving the extremely dangerous waste during 3 years. The decisions on extending a license have been motivated by the authorities by the borderline claims of an area being flood-free during periods of high water, absence of water-supply facilities and water-bearing beds in the vicinity of the dump site; that as if there are no inhabited localities nearby. They used to calm the criticallyminded environmental specialists that even if liquid industrial chemical waste moves down subject to gravitation force through a solid of clay to the in-depth water-bearing layer, there will be no threat in it: this will only happen after 968.5 years! Even if a maximum emergency discharge of toxic substances takes place through a drainage system to Neva, it is nothing at all serious. Nobody will even notice it, since a concentration of contaminants will be significantly lower than maximum permissible concentration (MPC), and it will be impossible to register such low level of contamination in the Gulf of Finland using instrumentation and hardware facilities [19]. The illusions of self-complacence (much like those existing on the eve of Chernobyl disaster) have just increased year after year. In 1978 a theory appeared stating that high degree of compactness of blue clays would prevent filtration of waste's liquid, since the pores in clay are filled with water, while a contact with petroleum products even improves the water resistance of rock - it fills the clay pores and completely blocks the filtration processes. Its falseness consists in the fact that the arrangement of toxic landfill site in blue clays is assessed as a mechanism ideally fitting the surrounding landscape and making it possible in the best way to use the properties of the clay solid not only for the benefit of community but for nature proper. After all, the property of water impermeability of blue clays was not demanded by nature for million years, so to say, presented and acknowledged in its practicality for the first time through arranging a dump site thereupon! It became clear by mid-1990s that the pits in Cambrian clay are not leakproof. The buried (filled up) toxic substances have penetrated into tectonic fractures irrespective of what rock fills the underground space. It has been proven that toxic substances have easily proliferated beyond the limits of landfill site at places of tectonic instability [20-22]. To suit the case another wrong theory has appeared saying that allegedly a contact of water with waste slurry ( $\mathrm{pH}$ from 0.5 to 13.5 ) will bring about a "self-healing" of the newly formed leakages (if any) due to clay swelling and adsorption processes, which certainly will get the "second breath" and will efficiently take place in the presence of just toxic chemicals and petroleum products. The clay itself will not "notice" its contamination; it will be just for its benefit. It is widely thought that nature will bear anything, that its ecological resources are unlimited. It is not for nothing that deputy A. Vasilenko sent a bill to the State Duma (Russian Parliament) in 2016 referred to as "On introducing changes into some legislative instruments of the Russian Federation in terms of arrangement (injection) 
of wastewater, industrial wastewater and waste in rock formations". In 2012 the suitability of the landfill site, though it has been already unfit for use by $100 \%$, was proven by I.V. Buldakov, the dean of geological department in his expert conclusion. Despite the extreme danger of the landfill site for eco-system and health of the people, the state structures (research institutes of hygiene, industrial pathology and human ecology, etc.) have characterized this place as the site meeting hygienic requirements to neutralization of production and consumption waste. In general, waste with high permeability has brought about contamination of lithosphere and hydrosphere, while harmful vapors have contaminated atmosphere of the surrounding territory [23]. The fires outbreaking repeatedly with emission of dangerous combustion products have just aggravated the grave negative situation and created even greater threat for vital functions of population of Tosnensky district, increased a risk of emergence of a disaster (Fig. 2).

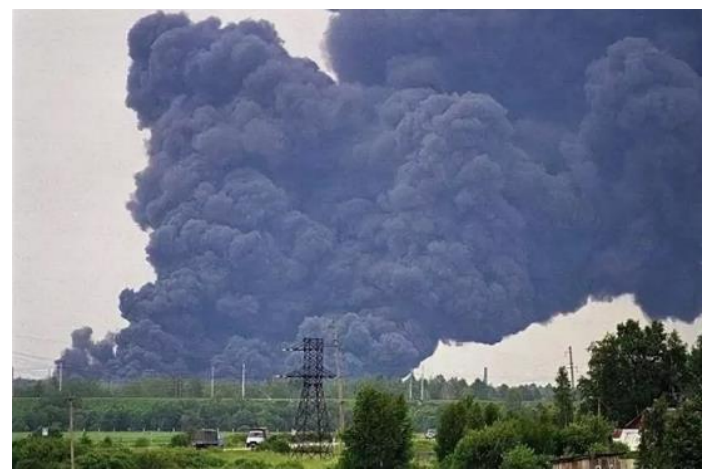

Fig. 2. Fire at "Krasny Bor" landfill site in 2014.

A sanitary protection zone of $3 \mathrm{~km}$ runs around the landfill site, where wide public resides permanently: about 2 thsd people, including 140 children at the age of 2 to 12 years. It contradicts the principles of ecological safety and protection of population against negative impacts and contaminants of the toxic landfill site. It should be emphasized that accumulation of about $0.1 \mathrm{~g}$ of $\mathrm{CO}$ in human organism causes death. In the process of fire in the cell the waste gas may happen to catch hydrogen sulphide, ammonia, formaldehyde, hydrogen cyanide (hydrocyanic acid), chlorine, phosgene, vapor of mercury, cadmium, zink, fly-ash comprising oxides and salts of heavy metals, exceedingly toxic PCDP, PCDF [24]. A pyrolytic decomposition of organochloride waste in the waste-to-energy installation of the dump site under technically unsuitable conditions most probably has been accompanied by emission of doses of dioxins hazardous for health. After banning incineration of harmful waste periodic fires started to outbreak at the landfill site. Before closing the installation there were 2 fires, after closing 8 fires happened (Fig. 3).

Presently, there are 5 cells ( 2 big and 3 small) in the territory of the landfill site with total volume of 700 thsd $\mathrm{m}^{3}$ subject to remediation. The water supply engineers, 60 fulltime employees effect permanent monitoring of water level in cells; excessive water is pumped out and supplied to a treatment installation. The landfill site is located in a seismically calm glade, which is, however, penetrated with deep tectonic cracks. The area of leakage at the bottom of a pit with toxic mixture was revealed in the eastern part of the landfill site just due to such tectonic distortions. The landfill site territory is characterized by utter overdamping: average annual precipitation is around $693 \mathrm{~mm}$; evaporation from the landfill site territory equals $150-400 \mathrm{~mm}$ [25]. In order to imagine the scope of concentration of toxic vapors in the cells, it is sufficient to mention the poisoned birds dropping inside from time to time. 


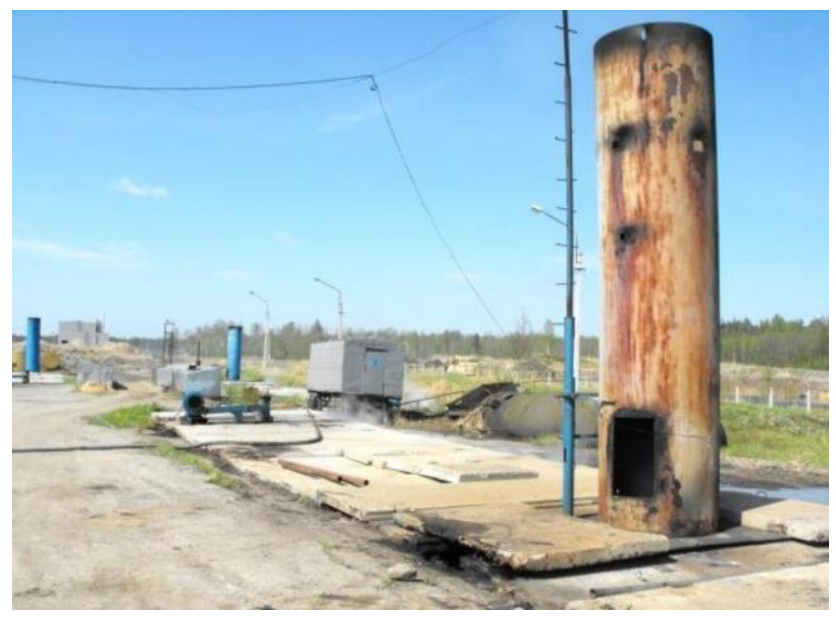

Fig. 3. Waste-to-energy installation at "Krasny Bor" landfill site, 2010.

Totally, around $2 \mathrm{mn} t$ of industrial waste of different class of danger has been brought all together to the landfill site of 70 pits, including 700 thsd $t$ of liquid and pastelike toxic waste with extremely unpredictable chemical "behavior", $3 \mathrm{mn} t$ of contaminated soil (Table 1).

Table 1. Composition of waste arriving at the landfill site.

\begin{tabular}{|l|c|l|}
\hline \multicolumn{1}{|c|}{ Waste description } & $\begin{array}{l}\text { Class of } \\
\text { hazard }\end{array}$ & $\begin{array}{l}\text { Waste dangerous } \\
\text { properties, } \\
\text { Placement method }\end{array}$ \\
\hline $\begin{array}{l}\text { Especially toxic substances: mercury compounds, Galvanic } \\
\text { waste comprising chromium (6-valent), cadmium, lead, } \\
\text { cyanides, toxic chemicals }\end{array}$ & $1-2$ & $\begin{array}{l}\text { Toxic. } \\
\text { Leakproof } \\
\text { containers at special } \\
\text { grounds. }\end{array}$ \\
\hline $\begin{array}{l}\text { Sedimentation after treatment of liquid industrial waste } \\
\text { comprising, basically, organic compounds: emulsin and } \\
\text { emulsols, waste of phenol and acetone production, waste of } \\
\text { paints, varnishes and lacquers, waste of raw rubber } \\
\text { production, waste of plastic material production, waste of } \\
\text { chemical and pharmaceutical industry, waste of household } \\
\text { chemicals, waste of alcohols production, waste of fat-and-oil } \\
\text { products. Waste of electro technical industry, contaminated } \\
\text { solvents }\end{array}$ & 3 & $\begin{array}{l}\text { Toxic paste like } \\
\text { substances. } \\
\text { Cells for organic } \\
\text { waste }\end{array}$ \\
\hline $\begin{array}{l}\text { Sedimentation after treatment of liquid industrial waste } \\
\text { consisting, basically, of non-organic compounds: waste of } \\
\text { galvanic production, waste of metals degreasing, waste } \\
\text { comprising liquid glass, waste of paper printing and } \\
\text { publishing industry, neutralized cyanic waste, etc. }\end{array}$ & 3 & $\begin{array}{l}\text { Toxic paste like } \\
\text { substances. } \\
\text { Cells for non- } \\
\text { organic waste }\end{array}$ \\
\hline $\begin{array}{l}\text { Hard industrial waste: soils comprising petroleum products, } \\
\text { other contaminated soils, tyres, hardened varnishes, paints, } \\
\text { mastics, construction waste }\end{array}$ & 4 & $\begin{array}{l}\text { Toxic hard } \\
\text { substances. } \\
\text { As thickeners for } \\
\text { subsequent closure } \\
\text { of cells. }\end{array}$ \\
\hline
\end{tabular}

Limestone is used to reduce high acidity in two operating cells-pits No.64 (130 $\mathrm{m} \times 200$ m) and No.68 $(90 \mathrm{~m} \times 105 \mathrm{~m}) .800 t$ of chalk in 2016, $500 t$ in 2017, more than $300 t$ in 
2019 were already filled into cells. $800 t$ more were procured for filling in 2020 . Table 2 details a composition of waste of these cells [19].

Table 2. Composition of waste in cells No.64 and No.68.

\begin{tabular}{|c|c|c|c|}
\hline No. & Substance & $\begin{array}{c}\text { Cell } \\
\text { No.64 }\end{array}$ & $\begin{array}{c}\text { Cell } \\
\text { No.68 }\end{array}$ \\
\hline 1 & $\mathrm{pH}$ & 2.2 & 6.9 \\
\hline 2 & Water, not less than, $\%$ & 96 & 94 \\
\hline 3 & Ammonia nitrogen, $\mathrm{mg} / \mathrm{l}$ & 590 & 875 \\
\hline 4 & Suspended substances, dust, carbon black, $\mathrm{mg} / 1$ & 170 & 1150 \\
\hline 5 & Phenol, $\mathrm{mg} / 1$ & 50 & 16 \\
\hline 6 & COD, $\mathrm{mg} / \mathrm{l}$ & 24 & 60 \\
\hline 7 & Organochlorine compounds, $\mathrm{mg} / \mathrm{l}$ & 23.0 & 8.0 \\
\hline 8 & Iron, $\mathrm{mg} / \mathrm{l}$ & 98 & 83.0 \\
\hline 9 & Chromium, mg/l & 11 & 11 \\
\hline 10 & Nickel, $\mathrm{mg} / \mathrm{l}$ & 3.9 & 4.2 \\
\hline 11 & Copper, $\mathrm{mg} / \mathrm{l}$ & 1.6 & 1.6 \\
\hline 12 & Cadmium, mg/l & 0.36 & 0.47 \\
\hline 13 & Plumbum, mg/l & 0.23 & 0.35 \\
\hline 14 & Tin, mg/l & 0.11 & 0.10 \\
\hline 15 & Vanadium, mg/l & 0.12 & 0.11 \\
\hline 16 & Mercury, mg/l & 0.011 & 0.0082 \\
\hline 17 & Synthetic surfactants (anionic surfactants), mg/l & 4.6 & 9.2 \\
\hline
\end{tabular}

Over a long period of time the following changes occurred in these "boilers" as a result of unidentified chemical reactions: the environment of the contents of the cells changed from neutral to acid; concentrations of some heavy metals (mercury, zinc, chromium, cadmium, vanadium, nickel, lead, copper) increased; the volume of dissolved petroleum products that are difficult to oxidize increased several times; COD indicator remained unchanged. This means that the amount of oxygen used for oxidation of organics has not changed, but it is still sorely lacking due to the increased content of organics. It is known that when the concentration of synthetic surfactants in water exceeds $0.3-0.5 \mathrm{mg} / \mathrm{dm}^{3}$, foam paste gets intensively formed on the surface of water body leading to violation of the oxygen regime. The synthetic surfactants in the bottom sediments of the river can become a source of the secondary pollution with phenols, aldehydes, and organic acids; they decompose slowly drawing a film over the surface of water body. In fact, a large number of different organic compounds appeared in the pits of the landfill site, including the most complex and not yet determined by modern methods. The presence of organochlorine compounds (DDT, HCH, hexachlorocyclohexane, heptachlor, kalgan, tiodan, etc.) in this toxic liquid poses a great danger to health [26]. The penetration of ammonium and its products into the human's internal organs leads to the denaturation of proteins and can cause cancer. Surface waters containing ammonium ions pollute the nearby streams and rivers. Safe exposure to dioxins is determined by the value of $0.1 \mathrm{ng} / \mathrm{m}^{3}$ featuring multiplicity factor of $10^{-10}$. In other words, in order to detect this dose, the device must have a sensitivity of $10^{-13}$ ! In practice, this means that it was not and still is not possible to determine this level at the landfill: it was in 2010 only that the plant for incineration of organohalogen compounds using fuel oil, which emitted a large amount of dioxins into 
atmosphere, was closed. The intensification of chemical reactions in an acidic environment threatens to damage the pits. Using observation wells at the boundaries of the landfill site it became possible to detect a mobile technogenic layer with a total area of 750 ha containing synthetic surfactants, phenols, formaldehydes, ammonia, heavy metals, petroleum products, and other pollutants. The level of surface water pollution beyond the northern part of the landfill site at a distance of $11 \mathrm{~km}$ turned out to be rather high and contrasting by the coefficient of total water pollution (from 1278 to 19), which confirmed the leakage of the cells [19]. The caustic pasty environment of cells serves as a source of increasing such harmful emissions as hydrogen sulphide, sulphur dioxide, carbon black, toluene, xylene, ethylbenzene vapor into atmosphere. It should be noted that, waste containing organochlorine after incineration can synthesize micro amounts of PCDDs and PCDFs at certain temperatures. But this is enough to cause irreparable damage to human health. The monitoring of such substances, primarily PVCs, PCBs, organochlorine resins and solvents in air, water and soil is considered mandatory in developed countries because of high environmental hazard thereof. Since, due to high toxicity they suppress the immune system and can form dioxins (tetrachlorodibenzo-p-dioxin (TCDD), etc.) as a result of successive reactions, the danger of these toxicants is extremely high: the penetration thereof into a human body causes the so-called "chemical AIDS" [26]. After court trials and speeches by environmentalists and public activists, it was forbidden to incinerate waste at the landfill site. However, since 2010 the EEC countries have banned the construction of landfill sites per se understanding the environmental damage they can cause to the living ecosystems and how expensive and economically inefficient they are (Directive 75/442/EEC).

The landfill site has a number of engineering structures that provide protection against increased surface runoff that forms in the spring:

- fire pond in the northwestern part of the landfill site with a capacity of more than 20 thsd $\mathrm{m}^{3}$;

- a drainage bypass channel around the landfill with a total capacity of more than 30 thsd $\mathrm{m}^{3}$, toxic water flows from it to the treatment facilities (building 115) and then the treated water through a drainage system enters the main canal, which flows into the Bolshoi Izhorets stream and then into the Neva river; runoff also flows through the Bezymyanny stream into the Tosna river;

- trunk channel equipped with a gateway regulator.

The annual runoff from the landfill site is $325-350$ thsd $\mathrm{m}^{3}$. The load from the internal territory with a significant increase in the volume of storm water is assumed by the sewer system and 4 storage ponds with a total capacity of 32 thsd $\mathrm{m}^{3}$, and when the regulating gateway is closed, the bypass channel acts as a temporary storage capacity in case of excess surface runoff and hazardous waste spill. However, in March 2016, an emergency occurred: the dam blocking the cells was broken and within an hour a powerful stream of toxic and harmful effluents poured into the Neva River. According to V. Kolyadov, before his appointment as the director of the landfill site the hidden pipelines led from the cells to the bypass channel, and then the drains were simply discharged into the forest and most often into the main canal. The purified water had a fetid odor due to process violation. Despite the warning of authorities about a possible breakage of the dam, Kolyadov was accused of an accident and fired. The case of a leak in the dam showed that neglect of environmental safety may lead to a catastrophe. According to the Finnish Environment Center, "the poisonous pool poses a threat of ecological catastrophe, hazardous waste from SaintPetersburg can get into the Gulf of Finland", "samples taken by the journalists of the Finnish newspaper Helsingin Sanomat show that the poison from the tanks leaks into the environment: the landfill site near Saint-Petersburg poses a serious environmental risk to the Gulf of Finland" [27-28]. Analysis of soil samples near the landfill site (in the area of 
the dam break) showed a high level of PCB biphenyls (even small amounts of polychlorinated biphenyls are extremely dangerous) and cadmium, which can cause cancer.

Before starting work for the landfill site remediation in order to improve the environmental safety of "Krasny Bor" landfill site, it was necessary to study the composition of the substances contained in the pit cells. It is rather difficult to do this because of unidentified chemical reactions between substances with the formation of new toxic compounds. Repeated fires could change the composition of chemical waste in cells under the influence of high temperatures. At the moment, two most urgent problems should be noted: one is associated with the determination of the chemical composition of substances in the pits; the other is related to stoppage and in some cases even preventing the spill of waste into the environment. Only after this it is possible to clean the pit cells and complete waste disposal with subsequent landfill site remediation (State Atomic Energy Corporation Rosatom was chosen as the contractor). It is planned to set up a nature park here in future, though it is hard to believe it.

In 2016 the containment of cells No.68 and No.64 was undertaken. The cell capacity was increased from $25 \mathrm{~m}$ to $33 \mathrm{~m}$ through the clay embankment [25]. 34 thsd $\mathrm{m}^{3}$ of toxic hazardous liquid of the 1st hazard class was pumped out of it into a temporary pit with a volume of 16 thsd $\mathrm{m}^{3}$. Obviously, only about half of the hazardous waste got into the temporary pit. Where did the other half go? It was "lost" in the intermediate cells (Fig. 4).

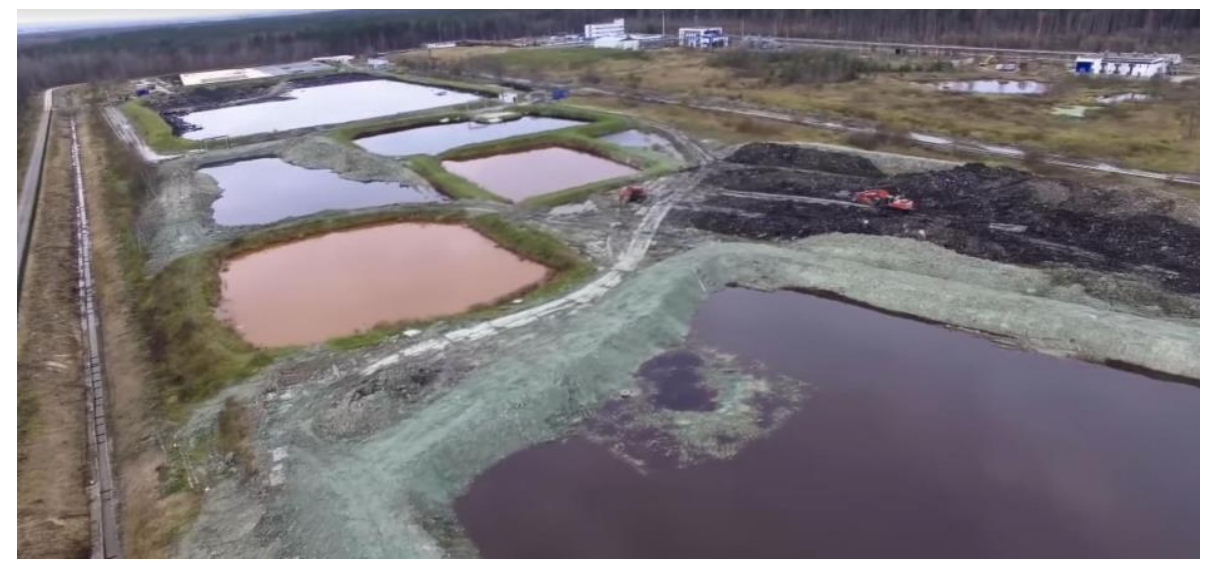

Fig. 4. Chain of intermediate cells for pumping toxic liquid into a temporary pit (in the foreground).

The containment of the cells was made of clay contaminated with class 1 waste, including cyanide compounds. As it turned out the emergency pits were dug at the place of disposal of especially harmful substances. Particularly hazardous substances from open repositories were moved to the surface and mixed with the surface layer of "soil", if you can call that the surface of the landfill site soaked with fuel oil, kerosene and other petroleum products.

Proceeding from the current situation on the dump site, it is possible to draw a preliminary conclusion: "boilers" with such chemically hazardous substances should be under reliable protection. According to safety rules (PB 06-123-96, para. 3.3) the landfill site must have a backup reservoir for an emergency, but such cell No.70 was closed back in 2005 , which indicates a gross violation of environmental safety requirements for facilities of high danger. 65 pits unused now are allegedly remediated. However, in reality they are only covered with a layer of clay and soil, and periodically fountains of toxic substances erupt through these layers. It is completely unknown what is happening in these pits and underneath. One thing is clear: continuous leaks take place from the dump site both into the underground waters of the 5-meter layer of the quaternary level on blue clays and into the 
deep aquifers with outlets on the southern part of the Gulf of Finland, through Sosnovy Bor, Lomonosov, Petergof, Strelna to Shlisselburg and further under Lake Ladoga. And this is not a self-soothing deception of the structures concerned but a scenario of an extremely dangerous situation of possible desertification of the North-West of Russia [25]. To date internal floating roofs have been installed on several cells (No.68 and No.64) and covered with a special anti-filtration coating (the Solmax 460 HDPE, $15 \mathrm{~mm}$ geomembrane has been deployed) so that existing waste does not mix with precipitation and does not exceed the specified pit volumes. Geosynthetic material is immune to low temperatures down to $75^{\circ} \mathrm{C}$, ultraviolet radiation, and chemicals. But such a technical solution worth P139.5 mn RUB still does not provide the leak-proofness and the complete exclusion of precipitation entering the toxic mass (Fig. 5).

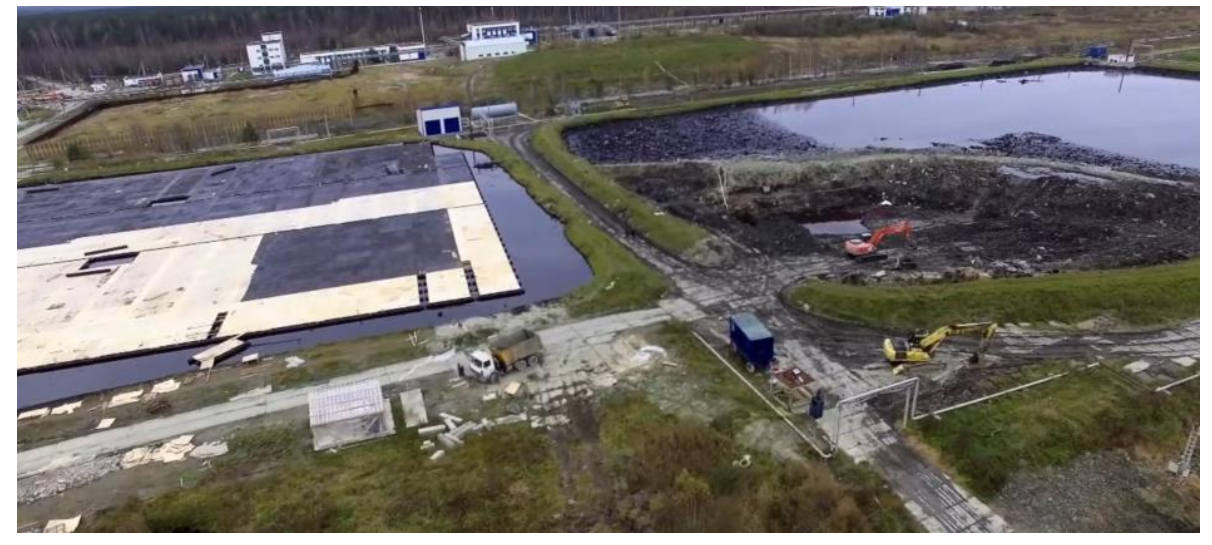

Fig. 5. Cell No.68 with inorganic waste is covered with internal floating roofs; in cell No. 64 with organics, the pit is deepened before containment.

Thus, a systematic assessment of the state of the landfill site as a whole allows us to predict a negative scenario of its operation and its transformation into the main factor that poses a threat of environmental disaster to the North-West of Russia.

\section{Discussion}

The screening of surface of the waste storage area could be a possible solution to ensuring environmental safety in the region. Based on the data obtained on the composition of the cell pits, the following design solution was suggested, approved by the Scientific and Technical Environmental Council under the Government of Saint-Petersburg. At the first stage complete processing of approximately 75 thsd $\mathrm{m}^{3}$ of inorganic waste and 210 thsd $\mathrm{m}^{3}$ of organic waste will be undertaken. Then the local soil contamination will be removed from the administrative area and the main canal with its disposal in pits No.67, No.66 and No.59. Finally, the remediated areas will be covered with a membrane screen made of a multilayer polymer material with high fire resistance, complete leak-proofness and protecting the cell from precipitation and the release of pollutants into atmosphere. This material is a copolymer of alternating structural units of ethylene and tetrafluoroethylene, which gives it the best properties of polyethylene and polytetrafluoroethylene (Teflon). A soil layer will be poured on top and a system created to collect the filtrate and discharge it to the municipal wastewater treatment plant. Part of this plan has already been implemented. The estimated cost of the entire project is about P3 bn RUB. During 20182020 Rosproject CJSC according to its patented development (worth P30 mn RUB) is to build the sewage treatment facilities, a sump tank for $240 \mathrm{~m}^{3}, 4$ pumping stations and 1 
transformer station, a building for biological and physical-chemical wastewater treatment (worth P480 mn RUB). It is planned to carry out treatment along four lines: the internal channel, the bypass channel and super-toxic cells No.64 and No.68. Lines' capacity will be $20,30,10$ and $5 \mathrm{~m}^{3} / \mathrm{h}$, respectively. The proposed layout will use preliminary, main and final treatment based on reverse osmosis. The organic compounds will be broken down via anodic oxidation units, and the oxygen released in this process will capture insoluble salts. This reject water will be pumped back into the pits, and the bulk of the treated effluents brought to necessary requirements will be discharged into the reclamation channel. The 68th cell will be remediated in 4 years, the 64th - in 13 years. By the end of this period only a meter-deep layer of concentrated sediment will remain in each cell. However, these are only plans so far! It is alarming that the environmental safety parameters of the treated effluents will be monitored by structures directly related to the dump site management: Unitary Enterprise "Vodokanal" of Saint Petersburg and the Central Laboratory for Analysis and Technical Measurements in the North-Western district. There are other disadvantages of this project. Even now new waste is being added to the cells, as there is nowhere else to deliver it. It is unclear what will be done with the reject water pumped back into the cells, and how it will be processed. Instead of shrinking through remediation, the landfill site, on the contrary, increased its territory: cell No.101 was added to cell No.100. There is no data on how chlorine-containing substances will be processed. The build-up and strengthening of the cell containment exerts destructive pressure on the underlying 5-meter layer of blue Cambrian clays and becomes the cause of groundwater contamination of this quaternary level. The construction of a 10 -meter wall around the landfill site to prevent the penetration of groundwater will only exacerbate the negative situation; it seems to be a completely useless and extremely expensive project (the construction of the fence costs P23 $\mathrm{mn}$ RUB, and the repair of the bypass channel will cost more than P10 mn RUB). The development agencies ignored the problem of contamination of the deep underground aquifer by the landfill site waste [20-22, 25, 29]. In Krasnoborsky, Nikolsky and other clay quarries natural resources are used destructively: sumps of quarries (the deepest parts of them) are punched; hydraulic windows are built over the aquifers (water intake of Strelna settlement and the Congress Palace), etc. The above technical solution for the restoration of the "Krasny Bor" seems economically ineffective without eliminating these violations fraught with environmental disaster. The subjective goal of minimizing the negative impact is radically at odds with the objective state of affairs: there is a maximization of the environmental threat of the landfill site and the invested funds for environmental protection measures are ineffective, and in some cases they are simply useless.

There are alternative dump site remediation options. The technology of a simple incinerator was declared unacceptable because of the uncertainty about the substances being formed during incineration of waste, which components poorly studied. In addition, it is unacceptable that pollutants enter the air after the construction of the plant. The method of thermal neutralization in an acidic environment proposed by the Ecology and Natural Resources Scientific Center of the Russian Academy of Sciences does not guarantee emission of dioxins formed during incineration of organochlorines into atmosphere. The representatives of the Institute of Physics of Saint Petersburg State University pointed out the catastrophic consequences of incinerating wastes containing PCBs. Once in the atmosphere, they can precipitate throughout the North-West. As an alternative, destruction technology was proposed: a plant using hard ultraviolet radiation and ozone. However, there is no guarantee at the toxic landfill site that extremely hazardous and harmful substances can be neutralized and disposed of appropriately using this method.

Nevertheless, one should not reject, but integrate all the useful technologies into the same project. The lithification method using the KAMK sorbent (Ecotech OJSC), localization and environmental neutralization technology (STC Technologiya XXI), 
decomposition method in the MSW photochemical reactor (Sovetsk, Kaliningrad region), and several others are among these [30].

There is another way to dispose of the toxic waste of "Krasny Bor" landfill site. These are the modern two-chamber incinerators (for example, IN50.1 from "Tourmaline") with the possibility of safe incineration of organochlorine compounds without emission of dioxins into atmosphere. They use the following PCB detoxification methods: catalytic oxidation, ozonation, oxidation under supercritical conditions, plasma methods. The recycling process allows controlling the technology of not just incineration, but $99.9999 \%$ destruction of PCBs without formation of molecular chlorine. This is achieved using the optimal ratio of oxidizing agent, PCB and hydrocarbon fuel, as well as temperature ( $>$ $\left.1200^{\circ} \mathrm{C}\right)$ and the residence time of the mixture in the combustion chamber $(>2 \mathrm{~s})$ [31]. 5 incinerators with a capacity of $40 \mathrm{~kg} / \mathrm{h}$ to 10 thsd $\mathrm{kg} / \mathrm{h}$ will resolve, but not remove, the problems of processing toxic waste from the landfill site.

The officially declared environmental efficiency is most likely inconsistent, since with the growing demand for raw materials and consumption full remediation of this facility on the basis of already adopted limited project, although possible, does not meet the goals of the sustainable development. Neither a clay curtain along the northern and western borders, nor geotechnical measures, nor the arrangement of buffer storage devices, etc. will provide environmental safety. Without a clear understanding that the ecosystem's response to unsustainable environmental management and human pressure will be the lack of an environmental reserve for the equilibrium and sustainable development of the surrounding region, landfill site remediation will be ineffective [1].

In this context it is necessary to create an operational independent (non-departmental) control body, empowered with the implementation of a unified scientific and technical policy in the field of environmental monitoring of the landfill. Its activities should be related to coordination of the development and implementation of environmental monitoring programs; regulation and control of the collection and processing of reliable data; storage of information, maintaining special data banks and coordination thereof with international environmental information systems; activities to assess and forecast the state of the environment, natural resources, the response of ecosystems and public health to human impact; the availability of integrated environmental information to a wide range of consumers. The significant capital investments must be directed towards preserving all the surviving elements of "Krasny Bor" ecosystem and the surrounding region. Determining the amount of necessary investment that should be aimed at preserving the ecosystem of the North-West remains an urgent task for future research.

\section{Conclusions}

The scientific foundations of environmental monitoring and environmental safety system allow drawing conclusions about the ecosystem of "Krasny Bor" dump site taking into account the analysis of modern technologies and an integrated vision of the world. Despite updating the status of the landfill site and launching the project for its remediation, the anthropogenic pressure on the environment continues to grow. The problems of contaminating a deep underground aquifer, waste of biological resources, etc., have not been resolved. The water basin of the entire North-West region is intensively destroyed through contamination of the surrounding drainage system with waste from the landfill site and clay quarries. Departmental confusion, poor management culture, and technocratic thinking make it difficult to solve many environmental issues regarding landfill site remediation (for example, the use of advanced incinerator technology for effective land remediation remains unsolicited). The general condition of "Krasny Bor" dump site is critical, if not catastrophic. Obviously, there is no longer an ecological reserve for the 
equilibrium and sustainable development of the surrounding region. The analysis of the problems of the landfill site indicates the need to create an independent structure focused on the protection of a quality environment in order to ensure the ecological safety of the region.

\section{References}

1. E.V. Eldina, Ekologicheskiy monitoring poligona zakhoroneniya toksichnykh otkhodov 'Krasny Bor'. Environmental monitoring of the toxic waste landfill 'Krasny Bor'. Zapiski Gornogo Instituta - Notes of the Min. Instit. 167(1), 64-66 (2006)

2. E. Smirnova, Ohrana okruzhajushhej sredy i osnovy prirodopol'zovanija [Environmental protection and environmental management] (SPbGASU, Saint Peterburg, 2012)

3. M. Alekseev, E. Smirnova, J. of Environ. Eng. and Scie. 11(3), 67-78 (2016) https://doi.org/10.1680/jenes.14.00012

4. B. Mishukov, E. Smirnova, Wat. Manag. 170(4), 184-197 (2017) https://doi.org/10.1680/jwama.14.00160

5. E. Smirnova, M. Alexeev, Environ. Scie. Poll. Res. 24(14), 12835-12846 (2017) https://doi.org/10.1007/s11356-017-8857-0

6. E. Smirnova, V. Zaikin, E3S Web of Conf., 91, Article 05030 (2019) https://doi.org/10.1051/e3sconf /2019910

7. E. Smirnova, Espacios, 39(22), (2018) https://www.revistaespacios.com/a18v39n22/18392240

8. E.J. Drobysheva, N.D. Solovyev, N.B. Ivanenko, M.Y. Kombarova, A.A. Ganeev, J. of Trace Elements in Med. and Biol. 39, 14-20 (2017) https://doi.org/10.1016/j.jtemb.2016.07.004

9. P.V. Kotiukov, I.Y. Lange, Intern, J. of Civ. Eng. and Tech. 10(3), 1471-1478 (2019)

10. R. Dashko, Y. Karpova, Intern. Multidiscipl. Sci. GeoConf. SGEM, 3, 85-92 (2016)

11. R. Dashko, Y. Lebedeva, Wat. Res., 44(7), 875-885 (2017) https://doi.org/10.1134/S009780781707003X

12. E. Smirnova, Ohrana okruzhajushhej sredy i osnovy prirodopol'zovanija [Environmental protection and environmental management] (SPbGASU, Saint Peterburg, 2012)

13. R. Heinberg, The End of Growth: Adapting to Our New Economic Reality (New Society Publishers Gabriola Island, BC, 2011)

14. D. Meadows, J. Randers, D. Meadows, Limits to Growth. The 30-Year Update (Earthscan, London, 2005)

15. B. Commoner, The Closing Circle: Nature, Man, and Technology (Knopf, New York, 1971)

16. V.I. Vernadsky, Biosphere and Noosphere (Airis-Press, Moscow, 2012)

17. N.F. Rejmers, Nadezhdy na vyzhivanie chelovechestva. Konceptual'naja jekologija [Hopes for the survival of mankind. Conceptual ecology] (Rossija molodaja, Moscow, 1992)

18. M.Y Slesarev, V.I. Telichenko, IOP Conf. Ser.: Mater. Sc. and Eng. 456, 012126 (2018) 
19. A.V. Marova, Metody obespecheniya ekologicheskoy bezopasnosti poligona 'Krasnyy Bor' na osnove riskologicheskogo podkhoda [Methods for ensuring environmental safety of 'Krasniy Bor' landfill based on the risk-based approach] (Doctoral thesis) (Russian State Hydrometeorological University, St Petersburg, 2011)

20. R.L. Dashk,o, I.Y. Lange, J. of Min. Inst., 228, 624-630 (2017) https://doi.org/10.25515 PM 1.2017.6.624

21. R.L. Dashko, P.V. Kotiukov, Proceedings of the 2018 European Rock Mechanics Symposium 'EUROCK2018: Geomechanics and Geodynamics of Rock Masses', 241248 (CRC Press, London, 2018)

22. A.A. Okolelova, N.G. Kasterina, A.S. Merzlyakova, Intern. J. of Environ. Probl. 1, 4958 (2005)

23. M.A. Pashkevich, T.A. Petrova, Intern. J. of Ecol. \& Develop., 30(3), 98-105 (2015)

24. D.I. Kofman, M.M. Vostrikov, Termicheskoye unichtozheniye i obezvrezhivaniye otkhodov [Thermal destruction and waste disposal] (Professional, St Petersburg, 2013)

25. V.M. Pitulko, V.V. Kulibaba, Reg. Ecol., 2(44), 43-51 (2016)

26. J. She, S.H.S. Ip, Y. Guan, D. Chen, H.-B. Moon, A. Roos, S. Shaw, The Handbk.of Environ. Chem., 49, 153-202 (2016) https://doi.org/10.1007/698_2016_457

27. H. Saavalainen, Helsingin Sanomat 28, helmikuuta (2016) https://web.archive.org/web/20160229160852/http://www.hs.fi/kotimaa/a14564596765 93

28. H. Saavalainen, Helsingin Sanomat. 13, maaliskuuta (2016) http://www.hs.fi/kotimaa/a1457754716698

29. H. Scharff, A. van Zomeren, H. van der Sloot, Waste Manag. \& Res.: The J. of the Intern. Solid Wastes and Publ. Cleans. Assoc., ISWA, 29(1), 30-40 (2011)

30. P.B. Taukin, Kompleks sredstv po zashchite okruzhayushchey sredy ot vozdeystviya toksichnykh otkhodov na poligone 'Krasnyy Bor' [A set of tools to protect the environment from the effects of toxic waste at the Krasny Bor landfill] (Doctoral thesis). (Poligon 'Krasnyy Bor', St Petersburg, 2004)

31. L.D. Hylander, H. Sollenberg, H. Westas, The Scie. of the Tot. Environ., 304, 137-144 (2003) https://doi.org/10.1016/S0048-9697(02)00563-6 